\title{
BOOKS FROM TIBET
}

BY

\section{H. R. H. Prince Peter of Greece and Denmark}

The Third Danish Expedition to Central Asia

$\mathrm{D}$ uring the course of my participation in the Third Danish Expedition to Central Asia, from 1950 to 1954 , it has been my good fortune to acquire a certain amount of books from that mysterious and, today more than ever, closed country, Tibet. It was at the request of the Royal Library of Copenhagen that the purchases were made, and with funds made available for the purpose by that institution.

The books of Tibet are loose-leaved, the paper is locally made of bark fibre, and the printing is done by means of wooden blocks, in which the characters (Tibetan is alphabetical) are carved in reverse. The face of such a block, a whole page, is smeared with ink, and an impression then made on the paper. The leaves are printed on both sides, the reverse being the continuation of the front and done in such a fashion that it can be read by simply turning the leaf over along its upper edge. Volumes are encased between two wooden covers, which are then wrapped up in a piece of cloth and tied up with tape or leather thongs.

Tibetan literature - which is extensive and still hardly known in the West - consists mostly of religious texts; but stories, legends, guide books, medical treatises, dictionaries, etc. are not unknown. The value of the religious texts consists mainly in that, in Tibet, there are translations of Sanskrit originals which no longer exist elsewhere. These can be reconstructed from the Tibetan, which, in nearly all cases, is a word for word rendering of the Indian Buddhist compilation. In some instances, indecd, where the original, believed to have completely disappeared, has been found again, it has been possible to verify translations into Sanskrit thus made, and the results have proved astonishingly accurate. This does not mean, of course, that there is no national Tibetan literature. On the contrary, there definitely is one, but it is still, I repeat, somewhat unknown in the West. 
The books acquired for the Royal Library of Denmark are principally the Buddhist Canon, the Kan-gyur, and the commentaries on the latter, the Tän-gyur. Both consist of a great number of volumes, the former of one hundred and the latter of two hundred and twenty-four, plus one volume of index, the lot constituting a rather bulky collection. In addition, sixty-six books of various description have been bought and dispatched to Copenhagen. A list of them will be found embodied in this article. Purchases are being continued at the time of writing.

It is hardly necessary to mention that getting books from Tibet, a country practically closed at all times, but today doubly so because of the Chinese military occupation, is no easy matter. The following narrative of how the Kan-gyur was obtained will serve to illustrate this.

In $195^{\circ}$ when I arrived at Kalimpong, in West Bengal, India, a hill station some fifty miles from the Tibetan frontier, I found there another member of the 3 rd DECA, Magister, now Museum Inspector, Halfdan Siiger, cand. theol. From him I got all the equipment of the Expedition that he had with him as well as a bank account in Calcutta, which he told me was for the express purpose of acquiring a Kan-gyur for the Royal Library of Copenhagen. He had not had sufficient time, he said, to obtain this book himself, as requested, but as I was staying on while he was going home (after two and a half years in the field), he thought I might have a better chance of succeeding in the quest than he had had. He recommended especially that the print should be clear and legible, as the Royal Library particularly did not want a smudged and badly printed work, as is, alas, often the case.

Without wasting any time, I began at once enquiring of my Tibetan friends in the area if they knew of any copy of the Kan-gyur for sale. I was aware, of course, that the best edition was made in Derge, in eastern Tibet, the blocks there being of copper, not of wood, and the printing consequently much sharper. But because Derge had already been under Chinese occupation for over eighteen months, it seemed hopeless to expect to get a copy from there.

There remained two other possibilities. Copies of the Kan-gyur are printed at Lhasa, the Tibetan capital, in the Government Press at Shö, Žol, just below the Dalai Lama's imposing palace, the Tse Potala; they are also done at Narthang, in the Tsang province, where, however, the monastery from which they are turned out specializes rather more in the printing of the Tän-gyur.

From my friends I got only negative replies to my enquiries, and it seemed hopeless to expect to find the book in a local collection of either 
a monastery or a private person. In those days, I still expected to be allowed into Tibet, at least as far as Gyantse at the end of the Trade Route from Kalimpong, in India, and so did not make any more efforts to try to get a copy on the spot. The Indian authorities, on whom permission for this stretch of road depended, were, however, to keep me out of Tibet, and thus, not having obtained a permit to visit Gyantse, I resigned myself to remaining in Kalimpong, trying to do as much as possible from there.

One day in March $195^{\circ}$, some time before the Chinese military entry into Tibet (which began on October $25^{\text {th }}$, I950), I was invited to tea at the house of an old friend of mine, the well-known Russian Tibetologist, Dr. George Nikolaivitch Roerich, also resident in Kalimpong. With him I found a visitor, the Tibetan envoy to Nanking in China, who was proceeding home to Lhasa in expectation of a new appointment. His name was that of the noble house of Tsatora, and he was known as the Dön Chöt Gya-nag Kenchung, or "the little abbot envoy to China".

In the course of the conversation, my friend Dr. Roerich, who knew about my desire to purchase a Kan-gyur, mentioned the fact to the Kenchung. The latter at once very generously suggested that he might try to help me. He said that he was now on his way to Lhasa, and that immediately on his arrival at his destination he would endeavour to discover if there were a Kan-gyur from the Shö, Žol printing press for sale. He added that he would let me know as soon as he could possibly find out, and that at the same time he would inform me of the price. When asked what he thought the cost would be approximately, he replied at least Rs. $4000 /-(\mathrm{Kr} .6000 /-$ in those days), plus transport to Kalimpong.

This was a much higher sum than the one which I had at my disposal, and I wondered if the Kenchung really knew. In the hope that I could, after all, beat down the amount later, I accepted the proposal and ordered the Kan-gyur then and there. It secmed well worth taking the risk.

I was further encouraged in my decision when only a month later I received a letter from the Dön Chöt Gya-nag Kenchung, in which he wrote (in the exaggeratedly flowery style which is usual to Tibet his letter began: "To the Lotus-footed Prince") that he had been successful on his arrival in finding a Kan-gyur in the Shö Printing Press, and that he was immediately dispatching it to me by caravan from the celebrated Radeng (Reting) monastery.

I gratefully acknowledged receipt of the letter, thanking the Tsatora Kenchung for having been so helpful and expressing my eager antici- 
pation of very soon receiving the promised book. I then settled down to await its arrival, confident that it would not be long before it was delivered to me in Kalimpong, and congratulating myself on having so quickly succeeded in obtaining it.

The whole summer of $195^{\circ}$ now passed without anything more happening at all. Occasionally I enquired of Tsatora's agent in Kalimpong, Ts'ha Trul-ts'hang, if there was any news, but to no avail. I sent another letter to Lhasa to try to find out what had happened to the Kan-gyur, which was, I had been told, just on the point of leaving. But there was no reply. Radeng's La-brang (dependency) in Kalimpong professed complete ignorance of the whole affair too when I asked them.

And then, suddenly, in December 1950, the manager of this same La-brang informed me that he had some news. It was to the effect that they had not been able to bring the loads down as expected, because the Kenchung had been appointed Chang-chi (that is Governor of the Northern Region, with his seat at Nag-chu-ka) and they had had to accompany him there first. In the meantime, their animals had all been stolen by highway robbers, and they were thus left without any pack transport. They assured me, however, that the Kan-gyur was in safety in the Tsatora Sim-sha (Mansion) at Lhasa, and that as soon as they had gathered a sufficient number of new animals together, they would bring it down to me.

Then came the news that the Chinese Communist armies were converging on Lhasa. It looked as if they would get there before it might be possible to get the eagerly sought-for books out, and I was on the point of giving the whole business up and of searching clsewhere. I even went so far as to write a letter to the Bhutan Durbar asking if they, by any chance, should have a Kan-gyur for sale. But from this source I received no satisfactory response, and the office of the Bhutan Agent in Kalimpong handed me back my letter with a verbal, negative reply. Why they did not give me a written answer I have still not been able to find out, although I suspect that, in accordance with their conventions, it would have been impolite and compromising to say no to me in writing.

And then members of the various noble and wealthy families of Tibet began arriving in Kalimpong, fleeing (although they were loth to admit it) before the Chinese advance, which was engulfing their country. Among these was a young man $\left.* * * * *_{1}\right)$, with whom I eventually became very

1) I am purposely omitting to give his name, as to do so, under the present conditions might compromise him in the eyes of the new rulers of Tibet. And I should not like to embarrass him thus when he has been so very helpful to us. 
friendly. I met him, like the Dön Chöt Gya-nag Kenchung, at Dr. George N. Roerich's one day when I had gone there for tea. Again, in a practically identical repetition of the previous occasion, I happened to mention the Kan-gyur at Lhasa, and how difficult it was to bring it down, and $* * * * *$ immediately suggested that he should come to my assistance. He said that his sister, who was married to a member of one of Lhasa's most prominent families, was about to send a large caravan down to India. He presumed that it would not be any trouble to her to take the Kan-gyur along with her own things and suggested that he should write to her, asking her to do so. I naturally accepted the proposal with alacrity, delighted that hope was thus revived of getting the Kan-gyur out of Tibet.

During January $195^{\mathrm{I}}$ my friend told me that he had received a reply from his sister, in which she agreed to bring the ordered book down to Kalimpong. She begged, however, to receive some monetary advance to cover transport expenses, whereupon I made out and handed to my friend a cheque for Ind. Rs. 400/-. To my surprise, however, he told me this was not enough. Prices had now soared, he said, especially since the Dalai Lama had moved with all his court to Yatung in the Chumbi valley, on the border of India. The cost of one pack animal, horse or mule, from the Tibetan capital to India, was now Rs. I35/-, whereas it had been only Rs. 5o/- a short while ago. There were not enough animals to go round, for His Holiness had requisitioned them all for his use, and the few remaining ones had naturally to be obtained at a very much higher price. The whole transport would necessitate an expenditure of about Rs. I350/-, he said, and he therefore requested me to give him Rs. rooo/- in advance.

I was rather reluctant to comply, as it seemed to me to be a rather risky proposition. There had been so many difficulties in the past already that I could not help wondering how I was to know if I would really get the Kan-gyur in exchange for this money (which was not mine) this time. And then, on reflection, I came to the conclusion that this was perhaps, after all, the last chance that we would ever have of getting the ordered volumes away from Lhasa. It was, then, worth the risk. Whereupon I made out another cheque for the balance of Rs. $600 /-$, making the mental promise to myself that I would personally repay the Royal Library if this ever proved to be a mistaken course which I had decided upon. I did, however, insist that my friend should give me a signed and sealed receipt in exchange, even if, should he fail in his engagement, I knew that there would be no possibility of enforcing compliance in a remote and closed country like Tibet. 
A letter was then dispatched by me to the Tsatora Sim-sha at Lhasa, informing them that my friend's sister would call for the Kan-gyur and instructing them to hand it over to her. In reply, I very soon after received a letter signed "your unseen friend Tse-ten Tub-den Tshö-tub", assuring me that this would be done. Enclosed in the letter was a seed of a large, pod-bearing tree, which Tibetans send you as a substitute for a presentation scarf (kathak), which they are hindered by distance from handing to you, as is their custom. I planted it in my garden, and it is today a fine, vigorously growing sapling. I then settled down to waiting again, hoping against hope that the Kan-gyur would be "evacuated" from Lhasa before the Chinese Communist armies arrived there, to stop, as I imagined then, all communication with India.

Three months passed thus, without my receiving even an inkling of news. In spite of repeated enquiries, nothing could be found out. This was very worrying, especially now that I had paid out Rs. I00o/- from the bank account in my care. Eventually, one day, I heard that the Kan-gyur had been taken from Tsatora's house in Lhasa and was in Gyantse, awaiting transport further south. It had not been possible to take it beyond this town, because all the pack animals belonging to my friend's sister had unfortunately also been requisitioned by the Dalai Lama's government in Yatung. Many animals were needed, it was explained, to carry supplies to the considerable number of people who were now camping provisionally in the Chumbi valley. At the same time came the disquieting news that, although the Chinese had not yet entered Lhasa, they were apparently attempting to by-pass the capital to the south and were already threatening the very city, Gyantse, in which the Kan-gyur was held up on its way to me.

I decided to telegraph to my friend, asking him to see to it that the book which we had worked so long to obtain was sent on to me by any means available. I emphasised that I did not at all like the idea of losing both the volumes and the money I had paid in advance, and ended by imploring him to attend to the business himself. The telegram was forwarded to Darjeeling, where I discovered that my friend had recently arrived, and in exchange I very soon after received a letter, in which he assured me that the Kan-gyur had already left Gyantse and was about to arrive in Kalimpong, as promised. I was overjoyed to hear this, but unfortunately could not remain in the station to receive the long-awaited dispatch. The deep-sea fishing Danish expeditionary ship "GalatheA" was just about then arriving at Calcutta, and I travelled down to the West Bengal metropolis to take part in the reception 
festivities to which I had been invited. It was while I was in Calcutta that I received word from my wife, who had not accompanied me, that the Kan-gyur had arrived on 26th April, I95I. It had been delivered at the dead of night by wild-looking caravaneers, who had handed her a letter from Tsatora in Lhasa and had vociferously insisted on receiving substantial "bakshish". The volumes were wrapped in eight bundles made of raw yak hide and seemed not to have suffered at all from the hardships of the journey. In the letter I was asked to pay the balance of the charges - and that was all. Final payment for the book could wait, I was told.

I was so elated by the news that I immediately telegraphed to Copenhagen: "Kan-gyur from Lhasa arrived". And on arriving back at Kalimpong, I immediately started making arrangements to convey the precious loads to Calcutta. They went there by truck to the aerodrome at Bagdogra, at the foot of the Himalayas, and on by air to Dum Dum. The whole consignment weighed 900 pounds, but it was safer and quicker to dispatch it by air freight. In Calcutta, the East Asiatic Company's local branch took charge of it, and very soon after it was sailing over the seas to its destination, free of charge, thanks to the generosity of the Company. Six weeks later it arrived at the Royal Library in Copenhagen, was unpacked, and, except for two volumes, was found to be in perfect condition. The two damaged volumes were later supplemented by means of microphotographs obtained through the courtesy of Professor G. Tucci of Rome.

When I was in Copenhagen in $195^{2}$, I visited the Royal Library and was shown the Kan-gyur, as it had now been catalogued in the Oriental Collection.

In an interview with the State Librarian, Mr. Palle Birkelund, I volunteered to obtain other Tibetan books if he so wished. I asked, however, to be given a list of the principal Tibetan works needed, and when I left in December $195^{2}$, I did so duly supplied with an exhaustive and comprehensive description of what I should get.

No sooner had I arrived back at my station than I set to work to try to procure these further volumes. My Tibetan friends had in the meantime all gone back to their country, recalled there by their government, so that there seemed very little chance of enlisting their help. Fortunately I made the acquaintance of a monk, an incarnation of the old, unreformed order, a Nyingma-pa Rimpoche, who eventually proved to be a very helpful contact.

Born in Sikkim but of Khampa (eastern Tibetan) parents, he was a 
big, burly man of attractive physique and much charm of manner. When I asked him to assist me in obtaining these books which I wished to acquire, he immediately agreed and assured me that he would very quickly be able to obtain the principal ones for me. He was perfectly true to his word and regularly, for over eighteen months, kept up a continual supply, very much on time and at remarkably reasonable prices. Where he procured the books from still remains a mystery to me, but I have learnt enough about Tibetan ways (lugsö) to know that one should not be inquisitive in these matters. As it was, it was sufficient for me and for him that he produced the goods. I suspect, however, that he had many acquiantances who either wanted to make a little cash or to rid themselves of volumes, not always acquired in a perfectly regular fashion. After eighteen months of this, the source seemed to dry up, and I was no longer able to get anything worth while from the Nyingma-pa Rimpoche.

Here is a list of the books which I obtained in this way, and which are now in the Royal Library of Copenhagen:

I. The poems and biography of Milarepa.

2. Biographies of Tilopa, Naropa, Marpa, etc.

3. The astrological work Baidurya karpo.

4. The Ka-thang de nga of Padmasambhava.

5. The Padma-Ka-thang.

6. The Mani ka-bum of Srong sän gam po.

7. Section of the Sung-bum (collected works) of Padma karpo.

8. Karchag to Lhasa monasteries (Ser-dre-ga sum) Yar lung and Radeng.

9. Karchag to the $\mathcal{J}$ a rung kha shor stupa in Kathmandu (Nepal).

10. Karchag to Mount Kailas and surrounding places of pilgrimage.

I 1. The Do-mang (collection of sutras), Ganden edition.

12. The Bar-do Thö-döl.

13. Part of the Gesar saga, Hor and Jang versions.

14. Chang-ling version of the Gesar saga.

15. An astrological compendium.

16. Biography of the Tibetan king Norbu Sang-po.

17. Sä-lung, a religious text of the Nyingma-pa.

18. Ri-rö, a Nyingma-pa text containing instructions for hermits.

19. Shä-dzö, an historical work.

20. Ts'he bang kur, text of ritual performed in honour of Ts'he-pa-me (Amitayus).

21. Leu-dün, a religious text of the Bön-kar.

22. A religious work of the Bön-kar.

23. Kusum tön, a religious text of the Bön-kar.

24. Lhasa Jo-khang Karchag, a guide to the Lhasa Cathedral. 
25. Ro-drong Tampe, a treatise by Nagarjuna II.

26. She-nying Dï-dog, a religious book of the Gelug-pa.

27. Chön-chug Drel-wa, a Kah-gyüd-pa commentary on the Boddhisatva Charia Avatara.

28. Chön-chug Tsa-wa, a text on the same from the Tän-gyur.

29. Tam-yig Kün-dï, a Druk-pa Kah-gyüd compendium of a Tantric commentary.

3o. Lung-ten, a Nyingma-pa prophecy.

3I. Men-pe, a book of Tibetan medicine.

32. Nye-gu tri-yig, a Kah-gyüd-pa commentary on Nye-gu, Naropa's sister.

33. Dö-mä dö-wa, an abridged text by Lama Gendün Gyamtso Palsang of the collection of the Taras.

34. Yang-kyer men-pe, a book of Tibetan medicine.

35. Ngag-bum, a Nyingma-pa text.

36. Samye Terma Karchag, an esoteric guide to Samye monastery. (Incomplete).

37. Sang-nying chi-ten, a commentary on Sri Guhya Garbha Tantra.

38. Thang-yig ser-threng, the life of Padmasambhava.

39. Lo-pän Ka-thang, the pronouncements of the Lotsawa and Pandita, one section of No. 4 , but in another edition.

4o. Naropä chö-chung, a religious treatise by Naropa.

4I. Ma chik nam-shä, the Chöd doctrine.

42. Gong-pa sang-thal, a ritual of the Dzok-chen-pa (Mindoling edition).

43. Dï-djom phur-pa, rituals of the Nyingma-pa sect.

44. Chuk-she karnag dra-sum, a Kah-gyüd-pa praise to Dam-pa Sang-gye.

45. Tur-chöd ngag-tön, a funeral service of the Kah-gyüd-pa.

46. Ka-pgye, eight special Dzok-chen-pa services.

47. Lha-dri nying-thig, chapter I of the Dzok-chen-pa "Heart Essence".

48. Sap-tön nyän-gyü, Chöd ceremonies of the Kah-gyüd-pa, with Kang-ling (bone trumpet) accompaniment.

49. Chag-gya chen-pa, Kah-gyüd-pa Mahamudras.

50. Kan-dro nyän-gyü, a religious text of the Gelug-pa.

51. Rab-nä-kyi Zin-dri, a Nyingma-pa consecration preparation. Rab-nä Chok trig, the proper text for a supplementary to the above. Cha-sum, the "Third Factor" offering - a ceremony against bad luck. Tra-gön, a Nyingma-pa preparatory ceremony.

52. Ser-dre-ga sum Karchag, a complete guide to the three great Lhasa monasteries of Sera, Drepung, and Ganden.

53. Suk-ki Nyimä Namtar, "The Story of the Light of the Body", a popular tale.

54. a) She-pa Tring-yig, a moral instruction of the Nyingma-pa by Nagarjuna, transcribed by P'hag-pa Lo-drup.

b) She-chä gön-che, Introduction to wisdom, a Nyingma-pa text by Sönam Senghe.

c) She-rab rel-tri, the double-edged sword of wisdom, a Nyingma-pa text by Jampel Kye-pa. 
d) Ten-del nying-po, the essence of inter-relationship, a religious text by Nagarjuna, transcribed by P'hag-pa Lo-drup.

e) Nä-kyi khyü-chä, medical instructions of the Nyingma-pa by Jampel Kye-pa.

55. P'hag-pa Shing-kün, a guide to Swayambunath, Kathmandu, Nepal.

56. Chu-drug Ki lo-t'ho, a Water-Dragon year calendar, 1952/53, from Men-dzi khang (Medical and Astronomical College) Lhasa, Tibet.

57. Gesar-ki Kang-söl, a supplication of King Gesar.

58. Gesar-ki Yang-drup, an invocation to King Gesar.

When in Denmark, I had also been asked by Professor Kaare Grønbech, Director of the Central Asia Institute, University of Copenhagen, to try to obtain a good copy of the Tän-gyur, if possible. This book, the two hundred and twenty-five volumes of which constitute the Commentaries on the Buddhist Canon, the Kan-gyur, is specially printed at Narthang, in the province of Tsang. The printing, however, has a bad reputation, and those who have obtained copies have usually complained of the smudged and hardly legible script which they have received.

In the spring of 1953 my friend $* * * * *$ from Tibet turned up again on a brief visit to India. I immediately made a point of meeting him and asked him if, since he had formerly been so helpful in bringing us the Kan-gyur down from Lhasa, he could arrange somehow for me now also to obtain a Tän-gyur from Narthang.

He answered that he would try. When I said that the edition should be a good and legible one, he replied that that could also be arranged. It sounded too good to be true. "How can that be done?" I asked. "Oh! quite simply," he said. "All that is necessary is, first, to get good paper, and next, to have the wooden printing blocks thoroughly cleaned."

He went on to explain that if I advanced him sufficiently he would be prepared to send one of his men to Walung in Upper Assam, on the borders of Tibet near the frontier town of Rima, where the road to Za-yul passes, to purchase good paper. He assured me that it was from that town that the best quality came, that upon which all first-class books in Tibet are printed.

I acquiesced in his demand and paid him a handsome sum to provide us with the right paper. I then gave him another substantial sum to pay the monks at Narthang Gompa (monastery), who would be kept busy for the rest of the spring, he told me. There would be no rain now until May or June, and the blocks would be taken out and washed. They would then be laid in the brilliant, high altitude sunshine of Tibet to dry, and the work of printing the Tän-gyur for us would com- 
mence after that. This, too, would be conducted in the open, the monk printers taking advantage of the dry sunny weather to complete the task under the best possible conditions.

I felt very proud at having given employment to a whole monastery in Tibet during the subsequent months. My friend went back to his country and soon after wrote to me to say that everything was going as planned. The paper had been purchased and delivered, the printing blocks had been thoroughly scrubbed and cleaned as never before, and the monks were now at work in the open, printing the Tän-gyur in the sunshine, upon long, wooden tables.

Soon after I was obliged to leave for Afghanistan to take over the leadership of the Danish Scientific Mission to that country, the Henning Haslund Memorial Mission. But I was away for only ten weeks, and when I returned to Kalimpong in the middle of August, it was to find that the now ready and completed Tän-gyur had arrived at Gangtok, in Sikkim.

A few days later it was delivered on my doorstep, wrapped up, as the Kan-gyur had been, in thick, raw yak hides. It seemed in perfect condition and so I did not open what I consider to be exceptionally good packing, and picturesque too, which never fails to make an exotic impression when it turns up in Europe.

The bales were forwarded to Calcutta in the same way as the Kangyur had gone earlier. Within two months, the two hundred and twentyfour volumes, plus the extra one containing the index, arrived in Copenhagen, and I received enthusiastic letters from both the State Librarian and Professor Grønbech, praising the quality of the printing. This was most satisfactory, and I felt that I had again been justified in laying out large sums in advance to obtain these results.

Later in the year my Tibetan friend came back again to India. This time he brought with him eight further books which I had asked him to try to obtain for me, as they were wanted by the Royal Library. They are as follows:

59. Baidurya serpo.

6o. Baidurya ngön-po (two volumes).

61. Deb ther ngön-po.

62. Tsong Kha pa's Dorji chang chen pö lam gyi rim.

63. Tsong Kha pa's Lam rim chen-mo.

64. Ist Pänchen Lama's Collected Works (volumes I-5).

65. Tibetan - Sanskrit Dictionary.

66. Sutra of the Great Bear. 
The Oriental Collection in Copenhagen has thus been enriched with all these much sought-for specimens of a little-known, yet rich Eastern literature.

At the time of writing, my friend has returned home, entrusted with yet another list, and I do not doubt that next time he emerges from his closed and mysterious highlands, it will be with yet another precious load of eagerly awaited books from Tibet.

Kalimpong, June, 1954 .

Editorial additional notes:

The bKa'-'gyur and the bsTan-'gyur, as well as the other Tibetan books, acquired by H.R.H. Prince Peter are kept in the Oriental Department of the Library as a separate collection, named "Prins Peters Samling", the individual books of which are marked with the numbers given by Prince Peter in the list above.

The books of this collection comprise the following subjects, the list of which should be taken as only tentative and very sketchy:

Astrology: Nos. 3, 15, 56, and 66.

Biography: Nos. 1, 2, 16.

Bon-po: Nos. 21, 22, 23.

Collected Works: Nos. 7,64 .

Dictionaries: No. 65 .

Gesar Saga: Nos. 13, 14, 57, 58 .

History: Nos. 4, 5, 6, I 9, 38, 39, 59, 6r.

dKar-chag or "Guides": Nos. 8, 9, 10, 24, 36, 52, 55.

Medicine: Nos. 31, 34, 60.

Tales: No. 53 .

Works of Nagarjuna: Nos. 25, 54 .

Works of Tson-kha-pa and dGe-lugs-pa: Nos. $11,26,50,62,63,64$.

Works of rÑin-ma-pa: Nos. I 7, 18, 30, 35, 43, 51, 54.

Works of bKa'-rgyud-pa: Nos. 27, 29, 32, 44, 45, 48, 49 .

Works of rDzogs-chen-pa: Nos. 42, 46, 47 . 